\title{
SNCB Gene
}

National Cancer Institute

\section{Source}

National Cancer Institute. SNCB Gene. NCI Thesaurus. Code C159259.

This gene may play a role in the inhibition of both cell death and alpha-synuclein aggregation. 